\title{
Proteomic analysis of a toxic dinoflagellate Alexandrium catenella under different growth phases and conditions
}

\author{
WANG DaZhi", LIN Lin, WANG MingHua, LI Cheng \& HONG HuaSheng \\ State Key Laboratory of Marine Environmental Science/College of the Environment and Ecology, Xiamen University, Xiamen 361005, China
}

Received November 3, 2011; accepted March 8, 2012; published online July 11, 2012

\begin{abstract}
Alexandrium is a widely spread dinoflagellate genus throughout many regions of the world, which not only causes the harmful algal blooms (HABs) but also results in the paralytic shellfish poisoning (PSP) throughout the world. This study compared protein profiles of $A$. catenella grown under different growth phases and conditions using a proteomic approach, and identified the differentially expressed proteins. The results showed that the expressions of proteins identified in three different regions of the gels, the groups 1, 2 and 3 proteins, varied significantly with the growth phases and conditions. Group 1 proteins and six Group 2 proteins were highly expressed at the initial, exponential and stationary growth phases, eight Group 2 proteins were highly expressed only at the initial phase, and Group 3 proteins were highly expressed at the exponential and/or stationary phases. However, all these proteins were expressed at low levels or were barely visible at the dissipation phase. The expressions of groups 1 and 2 proteins were low or barely visible in various growth conditions except in continuous darkness they were highly expressed. Group 3 proteins, on the other hand, were overexpressed in continuous illumination and expressed at low levels or barely visible in continuous darkness or under nitrate-starvation. The data from MALDI-TOF-TOF mass spectrometry demonstrated that these differentially expressed proteins were associated with macromolecular biosynthesis, photosynthesis, tRNA synthesis and DNA stability, stress response and cell division regulation. Synthetase was the major component of the altered proteins. This is one of the first comprehensive proteomic study of a dinoflagellate, A. catenella, that provides a fundamental understanding of the proteins involved in A. catenella growth and response to environmental stresses, and potential physiological indicator proteins related to growth and environmental stress have been identified.
\end{abstract}

dinoflagellate, Alexandrium catenella, growth phase, environmental stress, proteomics, MALDI-TOF-TOF MS

Citation: Wang D Z, Lin L, Wang M H, et al. Proteomic analysis of a toxic dinoflagellate Alexandrium catenella under different growth phases and conditions. Chin Sci Bull, 2012, 57: 3328-3341, doi: 10.1007/s11434-012-5160-9

Alexandrium is a widely spread dinoflagellate genus throughout many regions of the world [1,2]. It is well known that many species within this genus are able to produce paralytic shellfish toxins (PSTs), a family of potent neurotoxins, which specifically and selectively bind to the sodium channels in neural cells and subsequently result in paralytic shellfish poisoning (PSP) throughout the world. In the past few decades, the harmful algal blooms (HABs) formed by members of the Alexandrium genus have increased significantly in frequency, intensity and distribution, and this has resulted in serious economic and public concerns [3]. Considerable efforts have been devoted to study-

*Corresponding author (email: dzwang@xmu.edu.cn) ing the biogeography, ecology, physiology and toxicology of Alexandrium [4]; however, many basic biological questions are still unresolved and, in particular, studies into the molecular mechanisms involved in cell growth regulation and bloom generation are completely lacking. Traditional biochemical methods and molecular technologies are challenged by the large Alexandrium genome (up to $200 \mathrm{pg}$ DNA $\operatorname{cell}^{-1}$ ), the permanently condensed chromosomes and cell mobility $[5,6]$.

The growth of Alexandrium cells typically includes four distinct phases: the initial, exponential, stationary and dissipation phases. However, the molecular mechanisms that regulate the cell growth phases are not clearly understood. In photosynthetic dinoflagellates, cell division is gated by 
the circadian rhythm but cell cycle progression is still coupled to cell growth. Only those cells that attain sufficient growth during the light period proceed to the $S$ phase [7]. In eukaryotic cells, cell cycle progression is controlled by cyclins and cyclin-dependent kinases (CDKs). Their interactions drive the cell through the different stages of the cell cycle and subsequently regulate cell growth [8]. However, although a few cyclin-like proteins and CDKs have been found in dinoflagellates, little is known about cell growth regulation in these species [9-12]. In Prorocentrum triestium, for example, cell growth is regulated by phasespecific proteins that are present at different growth phases. It has been postulated that these proteins are cyclins that are regulated by environmental conditions such as nutrients and light [13]. It was only when surplus nutrients and adequate irradiance were available that these proteins were expressed and cell proliferation and growth were maintained.

Many studies have demonstrated that species from the Alexandrium genus have evolved various adaptation strategies to critical environments such as turbulence, nutrients, temperature, light and oxidative stresses [14-17]. The first response of any organism to environmental stress is usually at the biochemical level, mediating its adaptation to cellular stress. However, very few studies have investigated the stress response in dinoflagellates and the cellular mechanisms by which Alexandrium adapts to changing conditions are poorly understood. In Kerenia brevis, a dinoflagellate that causes extensive blooms in the Gulf of Mexico resulting in neurotoxic shellfish poisoning, stress proteins such as heat shock proteins and antioxidant enzymes were identified in cultures under stress conditions [18]. These proteins were reported to play an important role in the survival strategies of the cells under various environmental stresses. Therefore, it is reasonable to suppose that differential expression patterns of proteins could be used to infer the type or source of stressors and to indicate cellular stress in broad terms.

Proteomics is a global technique that provides effective strategies and tools for profiling and identifying the proteins of dinoflagellates. In contrast to conventional biochemical approaches that address one or a few specific proteins at a time, proteomic techniques allow the simultaneous isolation and identification of hundreds or thousands of proteins in one sample. In the past few years, the proteomic approach has been used to study dinoflagellates, and a few important functional proteins have been identified and characterized [19-23].

A. catenella DH01, a key HABs species, is widely distributed in the coastal waters of China. It causes PSPs and, in the past several years, it has formed extensive blooms in the East China Sea, making it of economic and public health concern. The losses in mariculture and the threats to human life due to exposure to PSTs have been documented [24]. Many efforts have been devoted to studying A. catenella blooms, but little is known about the mechanisms of blooming or about the physiological response to environ- mental stress at the biochemical and molecular levels [25]. In this study, protein profiles of A. catenella DH01 under different growth phases and growth conditions were compared using a proteomic approach. Specific proteins related to the growth phase and environmental stresses were identified, and the possible functions of these proteins and their roles in growth regulation and the stress response are discussed. The goal of this study was to provide a preliminary understanding of the mechanism of A. catenella growth and response to environmental stresses, and to identify potential physiological indicator proteins related to growth and environmental stress.

\section{Materials and methods}

\subsection{Organism and culture conditions}

A. catenella DH01 was isolated from the East China Sea and maintained in $\mathrm{K}$ medium [26] at $20^{\circ} \mathrm{C}$ under a $10: 14 \mathrm{~h}$ light/dark photoperiod at a light intensity of approximately $100 \mu \mathrm{mol}$ photons $\mathrm{m}^{-2} \mathrm{~s}^{-1}$ provided by fluorescent lamps. The "seed population" for the growth phase and growth conditions was prepared by inoculating $1 \mathrm{~L}$ of exponential $A$. catenella cells into $10 \mathrm{~L}$ of $\mathrm{K}$ medium. When the cells entered the exponential growth phase, synchronization of the cells was achieved by maintaining the cells in continuous darkness for $48 \mathrm{~h}$. At the end of the synchronization period, approximately $4 \times 10^{7}$ cells were harvested by centrifugation at $3000 \times g$. The cell pellets were rinsed twice with precooled sterilized seawater to avoid any carry-over of culture medium and extracellular proteins.

For the growth phase experiments, the synchronized cells were inoculated into $5 \mathrm{~L}$ flasks with $4.5 \mathrm{~L}$ of $\mathrm{K}$ medium and grown to an initial cell density of $1.5 \times 10^{3}$ cells $\mathrm{mL}^{-1}$. The cell density was monitored one every day and approximately $2 \times 10^{6}$ cells were harvested at the initial, exponential, stationary and dissipation phases for proteomic analysis.

The cultures to be used for the different growth conditions experiments were prepared as follows: the synchronized cells were inoculated into normal $\mathrm{K}$ medium and incubated in a normal light/dark cycle for one day until a steady state was reached. The light-stressed cultures were prepared by incubating the synchronized cultures first in continuous dark and then in continuous light for $48 \mathrm{~h}$ each. The temperature-stressed cultures were prepared by incubating the synchronized cultures in $13^{\circ} \mathrm{C}$ under a normal light/dark cycle, and approximately $2 \times 10^{6}$ cells were collected at days 5 and 10. The nutrient-starved and nutrient-addition cultures were prepared by inoculating the synchronized cells into either nitrogen- or phosphorus-limited $\mathrm{K}$ medium, and incubated in a normal light/dark cycle until the nitrogen and phosphorus in the media had been used up (data not shown). Nitrogen and phosphorus were added to the nitrogen- and phosphorus-depleted cultures respectively, at day 7 , followed by incubation for several days. Cell densities were monitored eve- 
ry day, and approximately $2 \times 10^{6}$ cells were harvested for proteomic study at day 7 for the nutrient-starved sample and at day 9 for the nutrient-addition sample.

\subsection{Protein extraction}

For protein extraction, approximately $2 \times 10^{6}$ vegetative cells of A. catenell DH01 harvested at the various growth phases and culture conditions were collected by centrifugation at $5000 \times g$ for $10 \mathrm{~min}$ at $20^{\circ} \mathrm{C}$. The pellets were subsequently transferred to a $1.5-\mathrm{mL}$ microcentrifuge tube, rinsed twice with autoclaved seawater, and centrifuged again at $5000 \times g$ for $30 \mathrm{~min}$ at $20^{\circ} \mathrm{C}$. The pelleted cells were used for protein extraction. The $0.5 \mathrm{~mL}$ of pre-chilled urea/Triton X-100 buffer containing $7 \mathrm{~mol} \mathrm{~L}^{-1}$ urea, $2 \mathrm{~mol}$ $\mathrm{L}^{-1}$ thiourea, $2 \%$ CHAPS (w/v), $2 \%$ Triton X-100 (v/v), $1 \%$ DTT (w/v) and $2 \%$ carrier ampholytes was added to the cell pellets. The pellets were broken using an ultrasonic disrupter (Model 450, Branson Ultrasonics, Danbury, CT, USA). Samples were chilled on ice between bursts of less than $10 \mathrm{~s}$ of sonication. Cell debris was removed by centrifugation at $15000 \times g$ for $30 \mathrm{~min}$ at $4^{\circ} \mathrm{C}$. The $0.5 \mathrm{~mL}$ pre-chilled $20 \%$ TCA/acetone (w/v) was added to the supernatant to precipitate the protein for $30 \mathrm{~min}$ at $4^{\circ} \mathrm{C}$. Then the supernatant was removed by centrifugation at $15000 \times g$ for $30 \mathrm{~min}$ at $4^{\circ} \mathrm{C}$. The pellet was washed 3 times by ice-cold acetone with 20 mmol L ${ }^{-1}$ DTT and was recovered by centrifugation at $15000 \times g$ for $30 \mathrm{~min}$ at $4^{\circ} \mathrm{C}$ each time. Residual acetone was dried in a speed Vac for about 5 min. Finally the powder was dissolved in $50 \mu \mathrm{L}$ rehydration buffer containing $8 \mathrm{~mol} \mathrm{~L}^{-1}$ urea, $2 \mathrm{~mol} \mathrm{~L}^{-1}$ thiourea $2 \%$ CHAPS, $2.8 \mathrm{mg} \mathrm{mL}^{-1}$ DTT, $0.5 \%$ IPG buffer and a trace of bromophenol blue.

\subsection{Protein determination}

Protein quantification in each sample was performed using PlusOneTM 2D Quant kit (GE Healthcare Life Sciences). Prior to the assay, protein extracts were desalted using ultrafiltration (Microcon, $3000 \mathrm{MW}$ ).

\subsection{Two-dimensional electrophoresis}

Each protein sample $(40 \mu \mathrm{g})$ was mixed with a rehydration buffer and then loaded onto IPG strips of linear $\mathrm{pH}$ gradient 4-7. Rehydration and subsequent isoelectric focusing was carried out in an IPGphor III (Amersham Biosciences, USA). Rehydration was performed overnight in the strip holder with $340 \mu \mathrm{L}$ of rehydration buffer. After rehydration, isoelectric focusing was performed as follows: $2 \mathrm{~h}$ at $100 \mathrm{~V}$, $2 \mathrm{~h}$ at $200 \mathrm{~V}, 1 \mathrm{~h}$ at $500 \mathrm{~V}, 2 \mathrm{~h}$ at $1000 \mathrm{~V}, 2 \mathrm{~h}$ at $4000 \mathrm{~V}$ and $6 \mathrm{~h}$ at $8000 \mathrm{~V}$. After the first dimension run, each strip was equilibrated for $20 \mathrm{~min}$ is about $10 \mathrm{~mL}$ equilibration buffer containing $50 \mathrm{mmol} \mathrm{L}^{-1}$ Tris pH 8.8, $6 \mathrm{~mol} \mathrm{~L}^{-1}$ urea, $30 \%$ glycerol, 2\% SDS, $1 \%$ DTT and a trace amount of bromophenol blue. The strip was then placed in fresh equilibration buffer containing 2.5\% iodoacetamide (instead of DTT) for another 20 min. Subsequently, a 12.5\% SDS- PAGE second dimension run was performed. The proteins were visualized by silver staining and three 2-DE gels were run for each sample. Unless stated otherwise, the 2-DE gels shown in the figures are representative of the three separate gel runs.

\subsection{Silver staining}

Silver staining was performed following the method of Wang et al. [27]. Briefly, the gel was fixed initially for $2 \mathrm{~h}$ in a fixation solution containing 40\% (v/v) ethanol and $10 \%$ $(\mathrm{v} / \mathrm{v})$ acetic acid. It was then sensitized in a solution containing $30 \%(\mathrm{v} / \mathrm{v})$ ethanol, $0.2 \%(\mathrm{w} / \mathrm{v})$ sodium thiosulfate, $6.8 \%(\mathrm{w} / \mathrm{v})$ sodium acetate and $0.125 \%(\mathrm{v} / \mathrm{v})$ glutaraldehyde, followed by washing with distilled water (three times for 5 min each). Then the gel was stained for 20 min in $0.25 \%$ $(\mathrm{w} / \mathrm{v})$ silver nitrate with $0.015 \%(\mathrm{v} / \mathrm{v})$ formaldehyde before washing with distilled water again (2 times for $1 \mathrm{~min}$ each). The gel was developed in $2.5 \%(\mathrm{w} / \mathrm{v})$ sodium carbonate containing $0.0074 \%(\mathrm{v} / \mathrm{v})$ formaldehyde. The reaction was stopped with $1.5 \%(\mathrm{w} / \mathrm{v})$ ethylenediaminetetraacetic acid, disodium salt.

\subsection{Image capture and analysis}

Images were made using a Gel-documentation system on a GS-670 Imaging Densitometer from Bio-Rad (USA) and 2-DE electrophoretogram matching software. Images were saved in TIFF format before analysis with ImageMaster 2D Ellite (GE Life Science, USA). Computerized 2-D gel analysis including spot detection, spot editing, pattern matching, and database construction was performed with the help of the Image Master 2D Elite and Melanie IV software. A 2-DE gel of A. catenella at the exponential growth phase was selected as the reference gel against which the other 2-DE gels were compared. After spot detection and matching, spot intensities were normalized with total valid spot volume to minimize nonexpression-related variations in spot intensity and to accurately provide semiquantitative information across different gels. Spot normalization was done by analyzing their relative volume (volume percentage). A one-way ANOVA (analysis of variance) test was used to analyze spot intensities among the different groups. Only protein spots showing a significance of $P<0.05$ and at least a 2.0-fold difference in abundance (ratio of mean normalized spot volume versus mean normalized spot volume of the reference gels) were considered as either up- or downregulated. The protein spots that met these criteria were selected for identification by mass spectrometry.

\subsection{In-gel digestion and mass spectrometric analysis}

The differentially expressed protein spots obtained under the various growth phases and conditions were manually 
excised from the silver stained 2-DE gels. The gel pieces were destained three times in $200 \mu \mathrm{L}$ of $50 \%$ acetonitrile (ACN) in $25 \mathrm{mmol} \mathrm{L}^{-1} \mathrm{NH}_{4} \mathrm{HCO}_{3}$ each for $20 \mathrm{~min}$. They were then incubated in $100 \mathrm{mmol} \mathrm{L}^{-1}$ sodium thiosulfate and $30 \mathrm{mmol} \mathrm{L}^{-1}$ potassium ferricyanide, rinsed three times in $25 \mathrm{mmol} \mathrm{L}^{-1} \mathrm{NH}_{4} \mathrm{HCO}_{3}$ and once in Milli-Q water, shrunk with $100 \%$ acetonitrile for $15 \mathrm{~min}$, and air dried at room temperature for $30 \mathrm{~min}$. The spots were reduced with $10 \mathrm{mmol} \mathrm{L}^{-1}$ dithioerythritol in $25 \mathrm{mmol} \mathrm{L}{ }^{-1} \mathrm{NH}_{4} \mathrm{HCO}_{3}$ for $30 \mathrm{~min}$ at $56^{\circ} \mathrm{C}$ and subsequently alkylated with $55 \mathrm{mmol}$ $\mathrm{L}^{-1}$ iodoacetamide in $25 \mathrm{mmol} \mathrm{L}^{-1} \mathrm{NH}_{4} \mathrm{HCO}_{3}$ for $20 \mathrm{~min}$ in the dark. The gel pieces were washed alternately with 25 mmol L ${ }^{-1} \mathrm{NH}_{4} \mathrm{HCO}_{3}$ and $\mathrm{ACN}$, and then air dried.

All gel pieces were incubated with $12.5 \mathrm{ng} \mu \mathrm{L}^{-1}$ sequencing grade trypsin (Roche Molecular Biochemicals) in $25 \mathrm{mmol} \mathrm{L}^{-1} \mathrm{NH}_{4} \mathrm{HCO}_{3}$ overnight at $37^{\circ} \mathrm{C}$. After digestion, the supernatants were collected. Peptides were extracted from the gel pieces first into 50\% ACN, $1 \%$ trifluoroacetic acid and then into $100 \%$ ACN. All extracts were pooled and dried by SpeedVac.

The dried peptide mixtures were redissolved in $0.5 \%$ TFA, and $1 \mu \mathrm{L}$ of peptide solution was mixed with $1 \mu \mathrm{L}$ of matrix (4-hydroxy- $\alpha$-cyanocinnamic acid in $30 \% \mathrm{CAN}$, $0.1 \%$ TFA) before spotting on the target plate. MALDITOF mass spectrometry and tandem TOF/TOF mass spectrometry were carried out using the 4800 Proteomics Analyzer at the Genome Research Center, The University of Hong Kong, China. Data were acquired using the positive MS reflector mode with a scan range from 900 to $4000 \mathrm{Da}$; five monoisotopic precursors $(\mathrm{S} / \mathrm{N}>200)$ were selected for MS/MS analysis. The peptide mass fingerprints (PMFs) and MS/MS spectra that were obtained were used for protein identification in an NCBI non-redundant database, RefSeq (updated December, 2010, containing 4607655 entries) using the Mascot search engine (Version 2.2, Matrix Science, London, UK). All mass values were considered monoisotopic and the mass tolerance was set at $75 \mathrm{ppm}$. One missed cleavage site was allowed for trypsin digestion; cysteine carbamidomethylation was assumed as a fixed modification and methionine was assumed to be partially oxidized. Results with CI (confidence interval) values of greater than $95 \%$ were considered to be a positive identification.

\subsection{Immunoblotting analysis}

To validate the protein identification made using the mass spectrometric data, Western blotting was conducted using the RuBisCO II antibody (donated by Prof. Senjie Lin from University of Connecticut, USA). After electrophoresis, the resultant 2-DE gel was electroblotted onto a PVDF membrane (Immobilon-P, $0.45 \mu \mathrm{m}$; Millipore, Bedford, MA, USA) at a constant current of $100 \mathrm{~mA}$ overnight at $4^{\circ} \mathrm{C}$ in a transfer buffer $\left(0.025 \mathrm{mmol} \mathrm{L}^{-1}\right.$ Tris- $\mathrm{HCl}, 0.192 \mathrm{mmol} \mathrm{L}^{-1}$ glycine, $20 \%$ methanol, $\mathrm{pH} 8.3$ ). After blotting, the membranes were blocked with PBS containing $5 \%(\mathrm{w} / \mathrm{v})$ non-fat dry milk powder at room temperature for $4 \mathrm{~h}$. After five 10 min washes in PBS buffer with $0.05 \%$ (v/v) Tween 20 (PBST), the membrane was probed with anti-RuBisCO II (1: 5000). Then the blots were incubated with a secondary antibody, horseradish peroxidase-goat anti-rat immunoglobulin $\mathrm{G}(\mathrm{IgG})(\mathrm{H}+\mathrm{L})$ (Santa Cruz Biotechnology, Santa Cruz, CA, USA) (1: 5000 dilutions) for $2 \mathrm{~h}$ at room temperature. The protein spots were incubated with ECL solution and exposed to imaging films (Amersham Biosciences) for detection. Using this method, four isoforms of $\mathrm{RuBisCO}$ II were recognized on 2-ED immunoblotting gel of A. catenella (Figure 1), which was consistent with the result from mass spectrometric analysis (Table 1).

\subsection{Statistical tests}

Abundance comparisons of the differential expression proteins of $A$. catenella DH01 under the various growth phases and growth conditions were performed. As stated above, a 2-DE gel of $A$. catenella at the exponential growth phase was selected as the reference gel. All measurements were replicated at least three times and the data are expressed as mean values \pm standard deviation (SD). Statistical analysis was carried out using one-way ANOVA or an independent-samples $t$-test to evaluate whether the means were significantly different among the different groups. Significant differences were indicated for $P<0.05$. Prior to one-way ANOVA, data were log transformed to meet ANOVA assumptions of normality and variance homoscedasticity.

\section{Results}

\subsection{Proteomic analysis of $\boldsymbol{A}$. catenella samples at different growth phases}

The growth curves of $A$. catenella in the nutrient-replete culture medium are shown in Figure 2. The initial cell density was about 1500 cells $\mathrm{mL}^{-1}$. The cells grew rapidly after

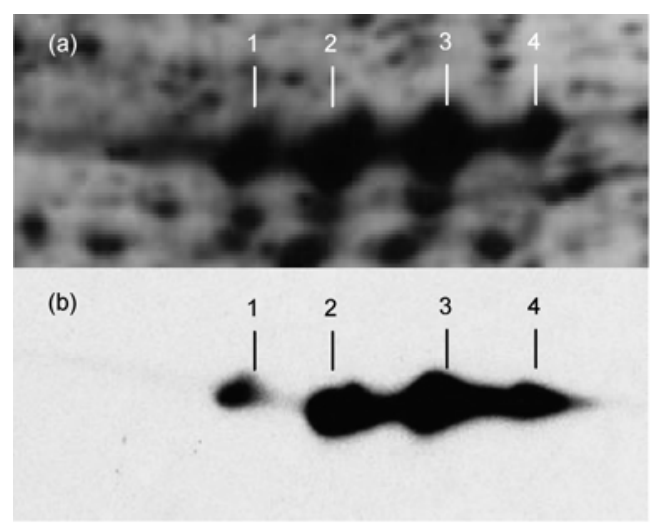

Figure 1 Detection of RuBisCO II in 2-DE immunoblotting gels of $A$. catenella. (a) Gel stained with silver stain; (b) the gel was electrotransferred to PVDF membrane and processed for Western blot analysis. 
Table 1 Identification of the A. catenella DH01 proteins that were differentially expressed under various growth phases and conditions using MALDITOF-TOF MS data to search the NCBI database

\begin{tabular}{|c|c|c|c|c|c|}
\hline $\begin{array}{l}\text { Spot } \\
\text { No. }\end{array}$ & NCBI & $\begin{array}{c}\text { Peptide } \\
\text { count }\end{array}$ & $\begin{array}{c}\text { Theoretical } \\
\mathrm{MW} / \mathrm{p} I\end{array}$ & $\begin{array}{c}\text { Sequence } \\
\text { coverage }(\%)\end{array}$ & Protein description \\
\hline 1 & 37727276 & 8 & $88757.3 / 5.89$ & 10.63 & ribulose 1,5-bisphosphate carboxylase oxygenase form II [Prorocentrum minimum] \\
\hline 2 & 37731773 & 5 & $31369.2 / 5.97$ & 14.49 & ribulose 1,5-bisphosphate carboxylase oxygenase form II [Prorocentrum minimum] \\
\hline 3 & 37731773 & 4 & $31369.2 / 5.97$ & 13.43 & ribulose 1,5-bisphosphate carboxylase oxygenase form II [Prorocentrum minimum $]$ \\
\hline 4 & 37727242 & 5 & $37878.5 / 6.19$ & 13.44 & ribulose 1,5-bisphosphate carboxylase oxygenase form II [Prorocentrum minimum] \\
\hline 5 & 112819975 & 4 & $12556.3 / 5.88$ & 33.04 & $S$-adenosylmethionine synthetase[Alexandrium minutum] \\
\hline 6 & 112819975 & 3 & $12556.3 / 5.88$ & 21.43 & $S$-adenosylmethionine synthetase[Alexandrium minutum] \\
\hline 7 & 112819975 & 5 & $12556.3 / 5.88$ & 33.93 & $S$-adenosylmethionine synthetase[Alexandrium minutum] \\
\hline 8 & 112819975 & 4 & $12556.3 / 5.88$ & 33.04 & $S$-adenosylmethionine synthetase[Alexandrium minutum] \\
\hline 9 & 112819975 & 4 & $12556.3 / 5.88$ & 33.04 & $S$-adenosylmethionine synthetase[Alexandrium minutum] \\
\hline 10 & 112819975 & 4 & $12556.3 / 5.88$ & 33.93 & $S$-adenosylmethionine synthetase[Alexandrium minutum] \\
\hline 11 & 112819975 & 3 & $12556.3 / 5.88$ & 33.04 & $S$-adenosylmethionine synthetase[Alexandrium minutum] \\
\hline 12 & 112819975 & 3 & $12556.3 / 5.88$ & 33.04 & $S$-adenosylmethionine synthetase[Alexandrium minutum] \\
\hline 13 & 112819975 & 3 & $12556.3 / 5.88$ & 33.04 & $S$-adenosylmethionine synthetase[Alexandrium minutum] \\
\hline 14 & 112819975 & 3 & $12556.3 / 5.88$ & 18.75 & $S$-adenosylmethionine synthetase[Alexandrium minutum] \\
\hline 15 & 83317733 & 3 & $6217.3 / 6.29$ & 20.35 & seryl-tRNA synthetase[Plasmodium yoelii yoelii str 17XNL] \\
\hline 16 & 29289943 & 15 & 92717.3/5.99 & 20.35 & sucrose synthase [Solanum tuberosum] \\
\hline 17 & 84324698 & 11 & $72310 / 5.98$ & 25.19 & COG3501: Uncharacterized protein conserved in bacteria [Pseudomonas aeruginosa 2192] \\
\hline 18 & 67969625 & 14 & $70432.5 / 5.65$ & 28.95 & unnamed protein product [Macaca fascicularis] \\
\hline 19 & 8050572 & 12 & $88207.5 /$ & 20.03 & elongation factor 2 [Euglena gracilis] \\
\hline 20 & 116219682 & 11 & $62821.5 /$ & 18.95 & hypothetical protein VchoV5_02002259 [Vibrio cholerae] \\
\hline 21 & 69935942 & 8 & $60343.4 / 6.04$ & 14.53 & Filamentation induced by cAMP protein Fic [Paracoccus denitrificans PD1222] \\
\hline 22 & 15625244 & 9 & $52612.3 / 5.69$ & 24.01 & 6-phosphogluconate dehydrogenase [Leishmania tropica] \\
\hline 23 & 71075884 & 12 & $130650.4 / 5.81$ & 10.90 & hypothetical protein GLP_464_15930_19427 [Giardia lamblia ATCC 50803] \\
\hline 24 & 71075216 & 10 & $68626.4 / 5.95$ & 18.35 & cell division protein [Giardia lamblia ATCC 50803] \\
\hline
\end{tabular}

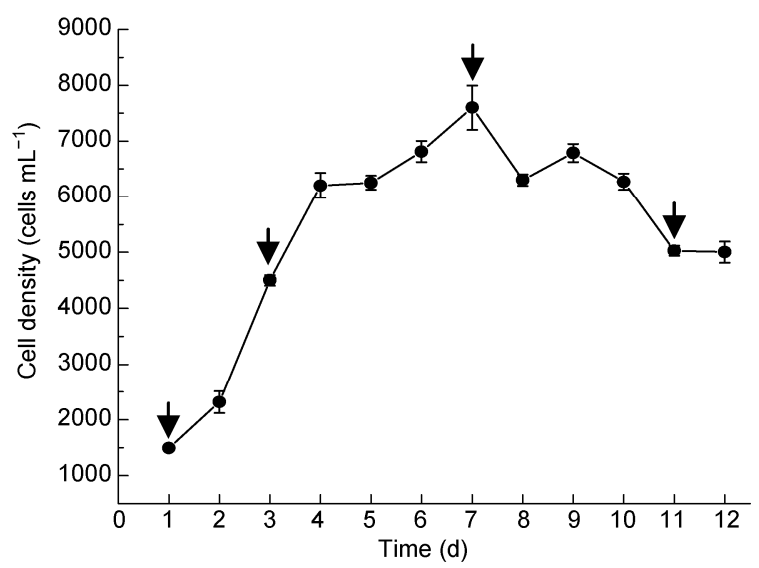

Figure 2 Growth curve of A. catenella DH01 in the nutrient-replete culture medium. Arrows show the sampling times.

the first day and reached the maximum growth rate at day 3; the cells then entered the stationary phase at day 4. After day 4 , the cell density remained relatively constant and reached a peak at day 7 before gradually dropping off. For protein extraction, the vegetative cells of $A$. catenella were collected at days 1, 3, 7 and 11 to represent the initial, exponential, stationary, and dissipation phases, respectively. The 2-DE protein profiles are shown in Figure 3. Most of the protein spots in the protein profiles are present in all growth phases. However, three groups of differentially expressed proteins (marked in Figure 3) at various growth phases were found (Table 2). The abundances of all the Group 1 proteins and 6 Group 2 proteins (spots 5 to 8,10 and 14) varied only a little in the initial, exponential and stationary growth phases, but decreased markedly or were barely visible at the dissipation phase. Proteins from Group 2, including spots $9,11,12,13,17,19,20$ and 21 were highly expressed at the initial growth phase but their expressions decreased or were barely visible in the other growth phases. Group 3 proteins, including spots 25, 26, 27, 28, 29, 33, 34, $35,36,37,38$ and 39 , were highly expressed at the exponential and stationary phases, but were expressed at low levels or were barely visible at the initial and dissipation phases. The expressions of group 3 spots 30, 31, 32 and 33 were highest only at the exponential growth phase. Other protein spots in Group 3, including 15, 16, 18, 22, 23 and 24 were relatively constant in abundance throughout all growth phases.

\subsection{Proteomic analysis of $A$. catenella samples under various nutrient conditions}

The growth curves of A. catenella under nutrient-starved 

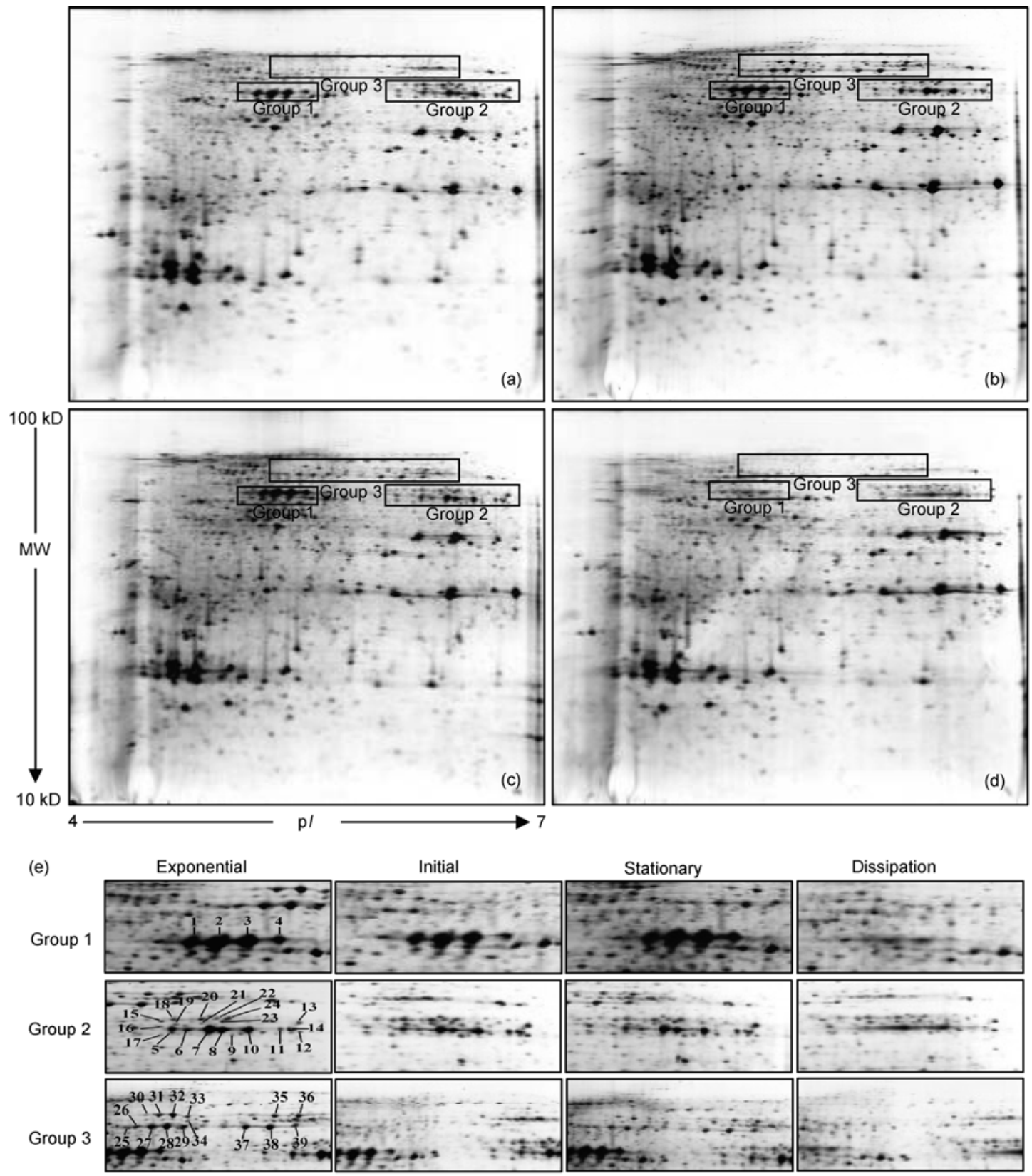

Figure 3 The 2-DE protein profiles ( $80 \mu \mathrm{g}$ of protein) of A. catenella DH01 during various growth phases. (a) Initiation phase; (b) exponential phase; (c) stationary phase; (d) dissipation phase; (e) expansion of the regions marked 1, 2 and 3 in panels (a)-(d). These regions correspond to groups 1-3 and the numbers in the exponential panel correspond to the spot numbers in Table 2.

and addition conditions are shown in Figure 4. The initial cell densities were about 1500 cells $\mathrm{mL}^{-1}$, cell densities then increased gradually for the first two or three days, after which the growth remained relatively constant because of the depletion of either the nitrate or phosphate. After nitrate or phosphate were added at day 7 , the cell densities increased rapidly and reached their peaks two to three days later.

The 2-DE gels of A. catenella at days 7 and 9 representing nutrient-starved and nutrient addition conditions, respectively, are shown in Figures 5 and 6. Compared to under nutrient-replete conditions, a majority of proteins of nitrate- or phosphate-starved A. catenella exhibited low expression; the proteins in groups 1, 2 and 3 were particularly affected. When nitrate or phosphate was added to the culture medium the expressions of all the groups 1-3 proteins increased (Table 2), indicating that these proteins were regulated by nutrients. In nitrate-starved condition, the vast majority of proteins from groups 1-3 presented low or no expression; however, the expressions of Group 3 proteins increased and presented a similar pattern as the nitrate-replete condition when nitrate was added to the nitrate-starved A. catenella. Proteins from groups 1 and 2 presented no difference between the nitrate-starved and addition cultures (Figure 5). Under phosphate-starved conditions, the expressions of the 
Table 2 Comparison of the abundances of the differentially expressed proteins of $A$. catenella DH01 under various growth phases and conditions

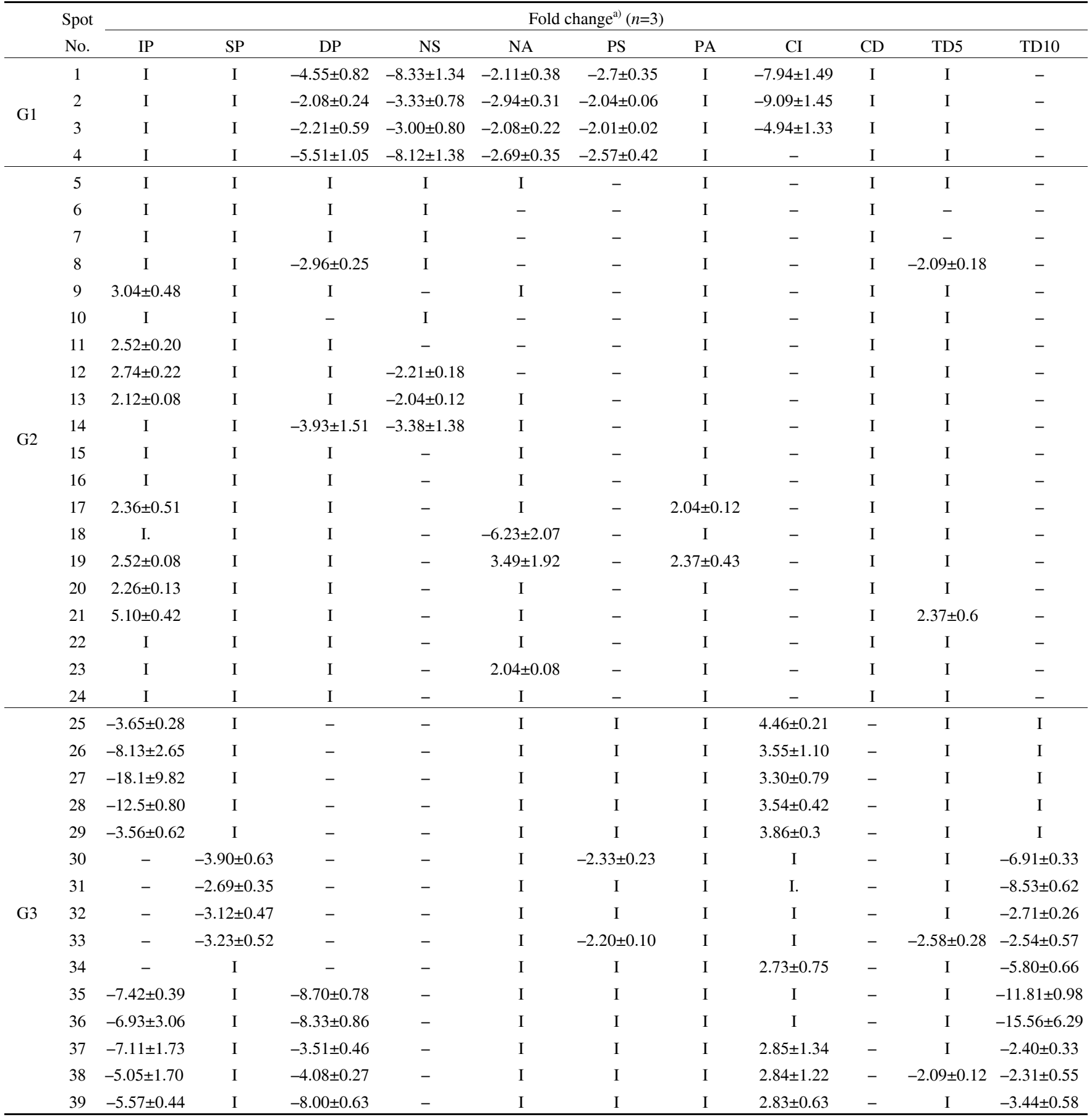

a) A 2-DE gel of A. catenella at the exponential growth phase was selected as the reference gel. Only fold changes ( $\geqslant 2$-fold or $\leqslant-2$-fold) are shown. Values $\geqslant 2$ indicate up-regulation; values $\leqslant-2$ indicate down-regulation. G1, group $1 ; \mathrm{G} 2$, group 2; G3, group 3; IP, initial growth phase; SP, stationary growth phase; DP, dissipation growth phase; NS, nitrate starved; NA, nitrate addition; PS, phosphate starved; PA, phosphate addition; CI, continuous illumination; $\mathrm{CD}$, continuous darkness; TD5, at $13^{\circ} \mathrm{C}$ at day 5 ; TD10, at $13^{\circ} \mathrm{C}$ at day 10 . In the table, "-" indicates the disappearance of the protein spot; "I" indicates the fold change for this protein spot was not significant.

proteins in Group 3 were not affected by phosphate depletion; whereas, proteins in groups 1 and 2, especially the proteins in Group 2, exhibited low expressions when phosphate-starved. When phosphate was added back to the cultures, the expressions of these proteins increased significantly (Figure 6).

\subsection{Proteomic analysis of $A$. catenella samples under environmental stress}

The 2-DE gels for $A$. catenella under continuous illumination and darkness (48 $\mathrm{h}$ for each) are shown in Figure 7 . The expressions of the majority of proteins under continuous 

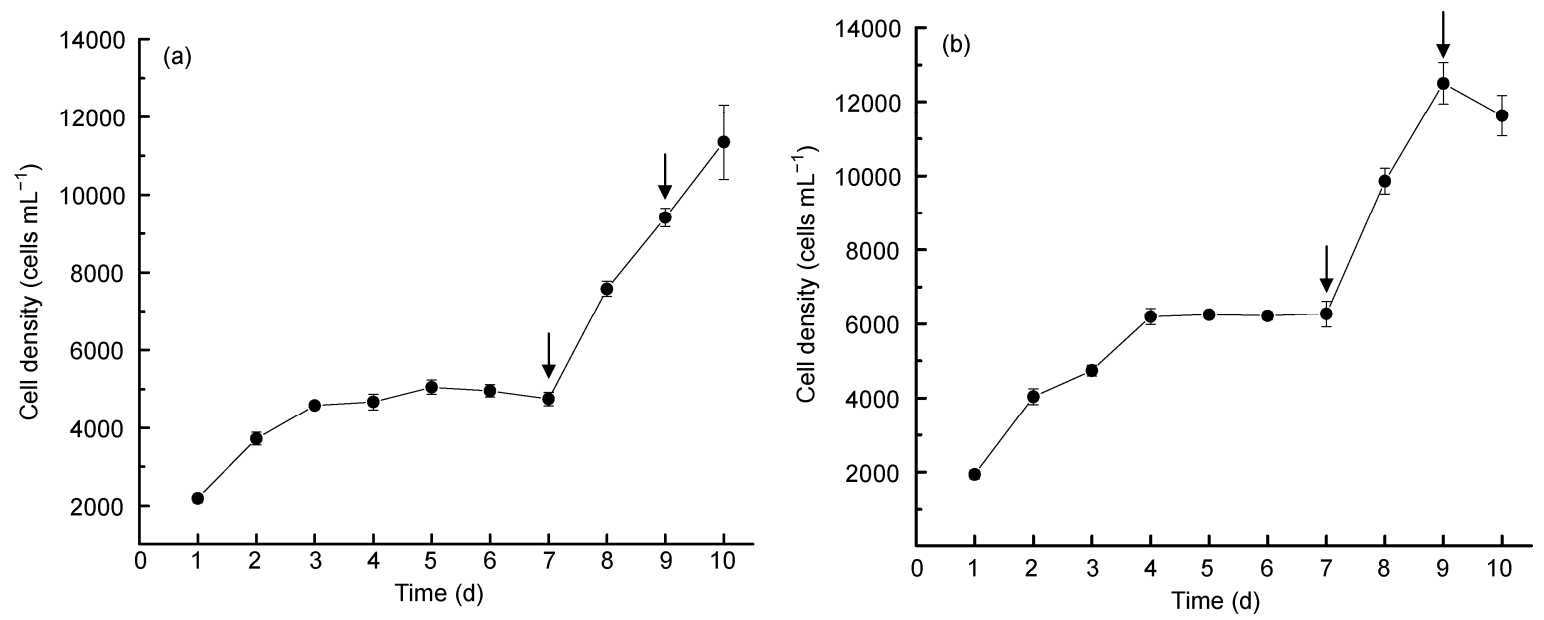

Figure 4 Growth curves of A. catenella DH01 nutrient-starved and, after addition of nutrients, nutrient-replete conditions. (a) Nitrate-starved and nitrate-added conditions; (b) phosphate-starved and phosphate-added conditions. Arrows show the sampling times.
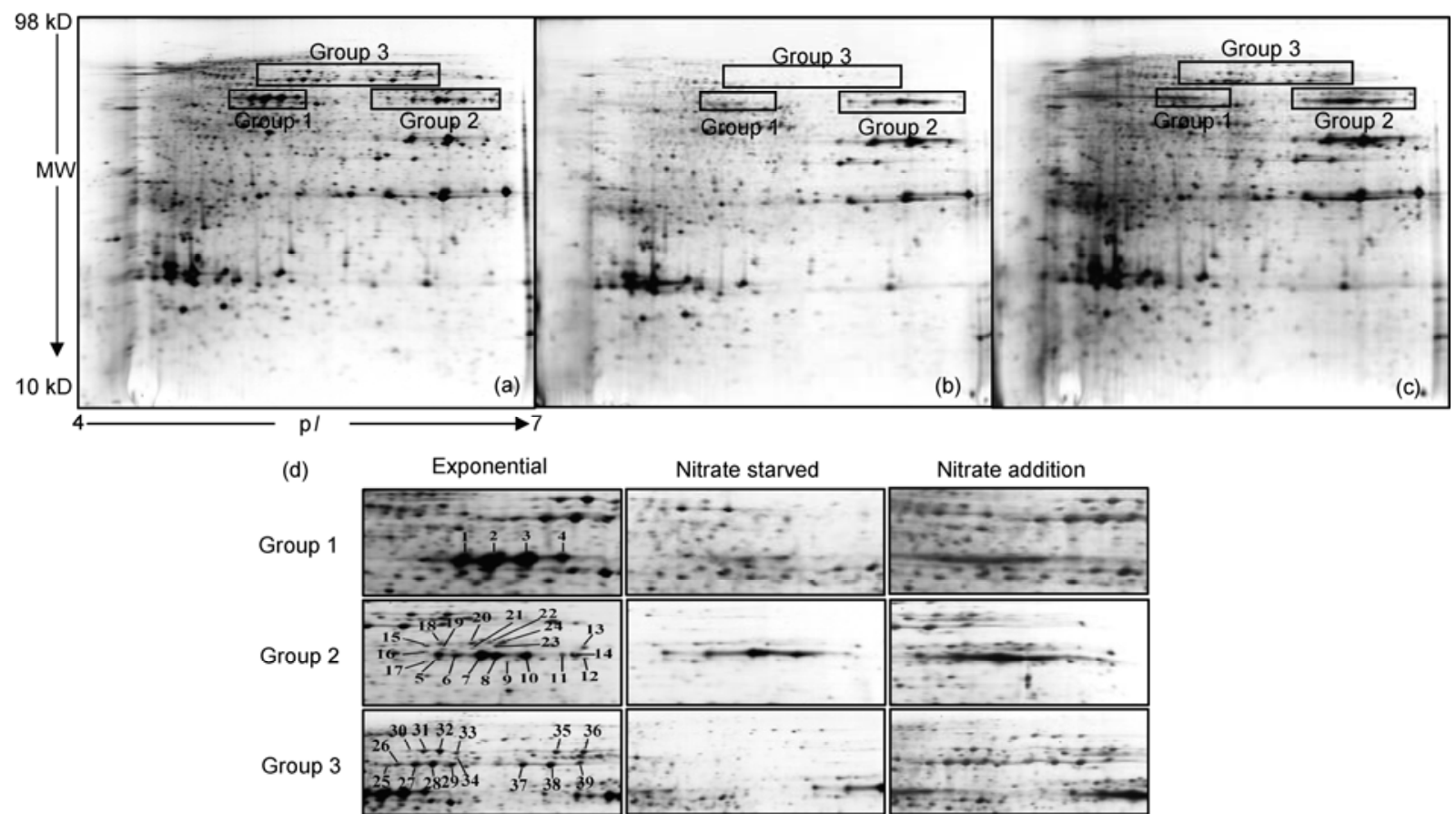

Figure 5 The 2-DE protein profiles ( $80 \mu \mathrm{g}$ of protein) of A. catenella DH01 in nitrate-starvation and, after the addition of nitrate, nutrient-replete conditions. (a) Exponential growth phase; (b) nitrate-starved culture; (c) nitrate-replete addition culture; (d) expansion of the regions marked 1 to 3 in panels (a)-(c). These regions correspond to groups 1,2 and 3 and the numbers in the exponential panel correspond to the spot numbers in Table 2 .

illumination or darkness varied little compared to their expressions during normal light/dark cycles. However, proteins in groups 1, 2 and 3 did vary significantly (Table 2). The expressions of groups 1 and 2 proteins decreased markedly in the 2-DE gel of A. catenella under continuous illumination, but varied only a little under continuous darkness. The expressions of the majority of Group 3 proteins increased significantly under continuous illumination and decreased markedly under continuous darkness.

The 2-DE protein profiles of A. catenella under low temperature conditions are shown in Figure 8. After incuba- tion at $13^{\circ} \mathrm{C}$ for $5 \mathrm{~d}$, no significant difference in protein expressions was found between the cultures grown at normal temperature and those grown at low temperature, proteins in Group 2 were an exception to this and the individual proteins could not be recognized (Table 2). Under continuous low temperature conditions, the expression of all Group 1 proteins and a majority of Group 2 proteins disappeared at day 10; the protein spots in Group 2 merged to a line and no distinctive proteins could be observed. The expression patterns for the majority of Group 3 proteins significantly decreased and were barely visible at day 10 . 

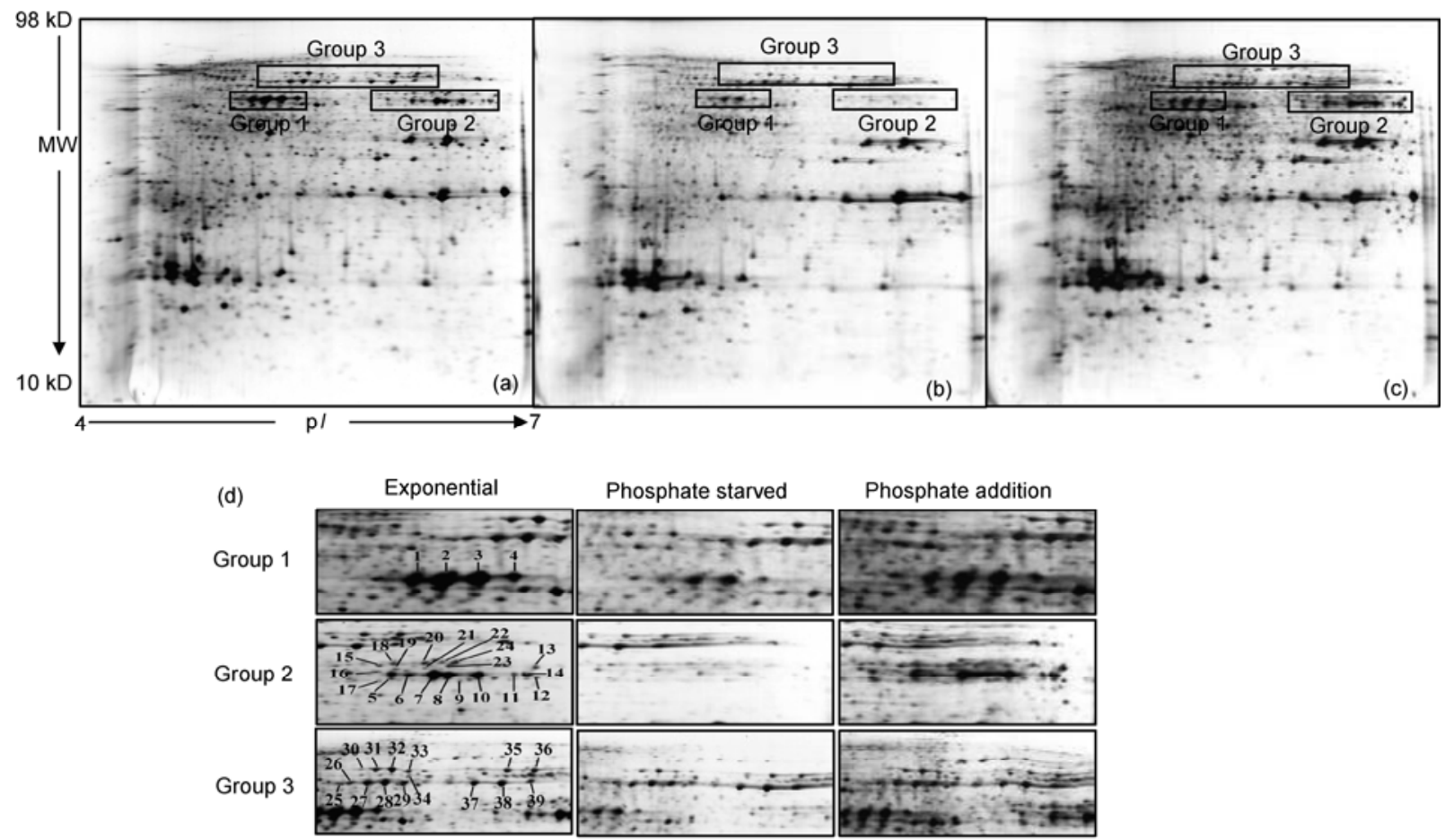

Figure 6 The 2-DE protein profiles ( $80 \mu \mathrm{g}$ of protein) of A. catenella DH01 in phosphate-starvation and, after the addition of phosphate, phosphate-replete conditions. (a) Exponential growth phase; (b) phosphate-starved culture; (c) phosphate addition culture; (d) expansion of the regions marked 1 to 3 in panels (a)-(c). These regions correspond to groups 1-3 and the numbers in the exponential panel correspond to the spot numbers in Table 2.
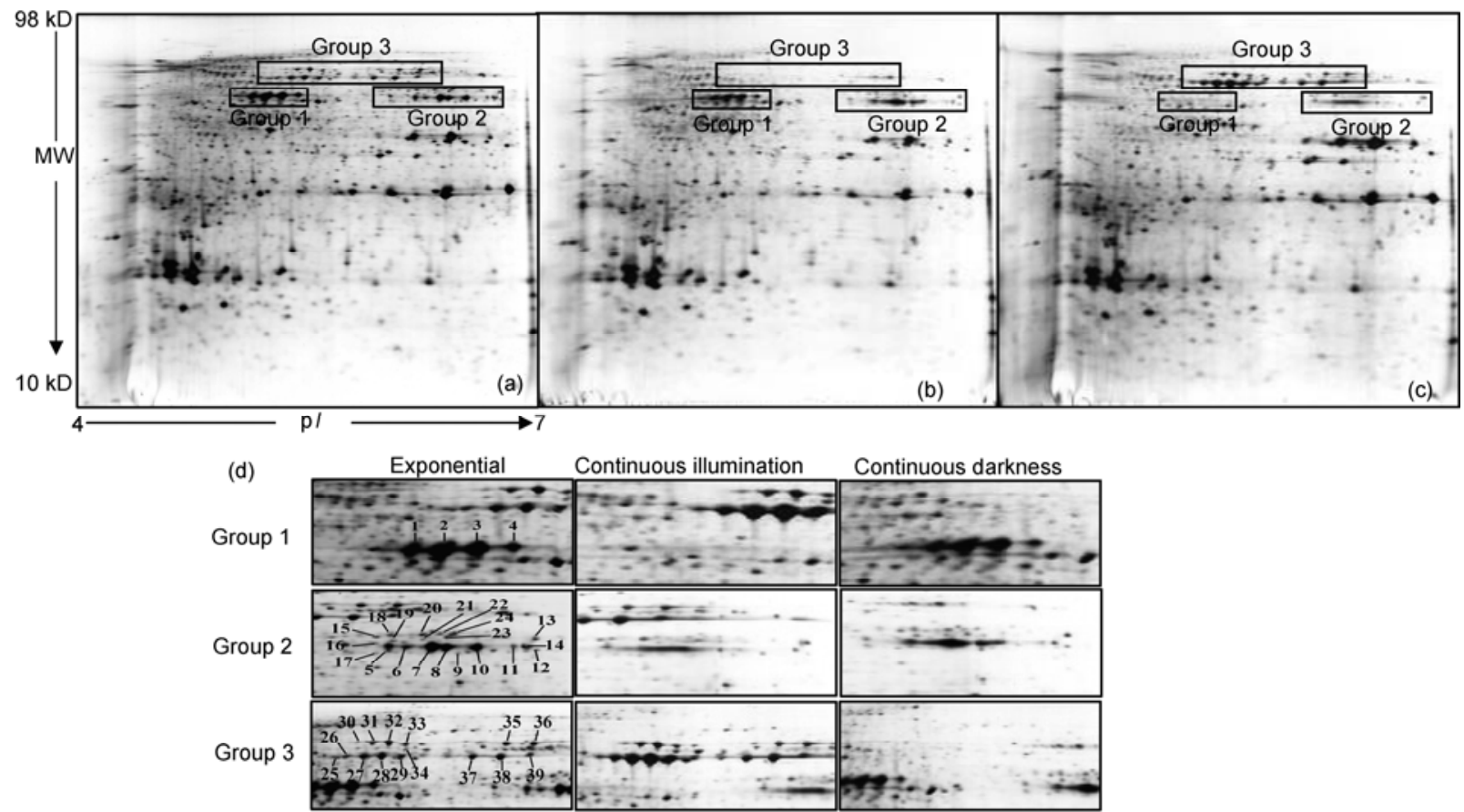

Figure 7 The 2-DE protein profiles ( $80 \mu \mathrm{g}$ of protein) of A. catenella DH01 under light stress conditions. (a) Exponential growth phase; (b) continuous darkness; (c) continuous illumination; (d) expansion of the regions marked 1 to 3 in panels (a)-(c). These regions correspond to groups 1 , 2 and 3 and the numbers in the exponential panel correspond to the spot numbers in Table 2.

\subsection{Protein identification by MALDI-TOF-TOF mass spectrometry}

All of the altered protein spots were selected for identification using the MALDI-TOF-TOF mass spectrometry in searches against the NCBI nonredundant database (RefSeq). The differentially expressed proteins that were identified under different growth phases and growth conditions represent a 


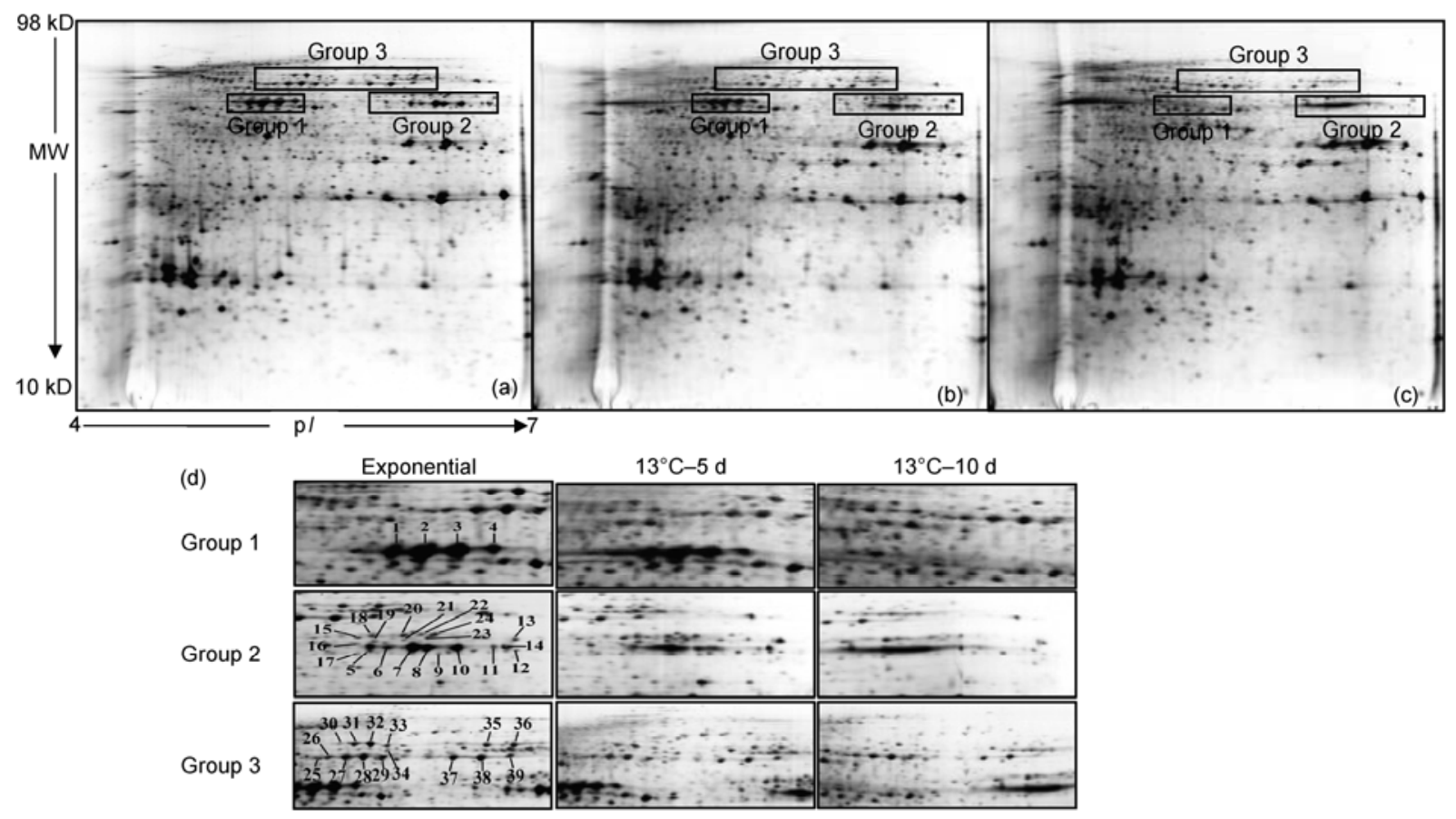

Figure 8 The 2-DE protein profiles ( $80 \mu \mathrm{g}$ of protein) of $A$. catenella $\mathrm{DH} 01$ under temperature stress conditions. (a) Exponential growth phase; (b) at $13^{\circ} \mathrm{C}$, at day $5 ;$ (c) at $13^{\circ} \mathrm{C}$, at day 10 ; (d) expansion of the regions marked 1 to 3 in panels (a)-(c). These regions correspond to groups 1,2 and 3 and the numbers in the exponential panel correspond to the spot numbers in Table 2.

heterogeneous group (Table 1) that are annotated to be involved in a variety of cellular biological processes, such as macromolecular biosynthesis, photosynthesis, tRNA synthesis and DNA stability, stress response and cell division regulation. Among all of the characterized proteins, synthetase/synthase was the most represented. Synthetases are involved in the synthesis and metabolism of amino acids, proteins, terpenoids and polysaccharide, and, in the $A$. catenella cultures, their expression varied with the growth phases and growth conditions.

Spots 5 to 13 were identified as multiple isoforms of $S$-adenosylmethionine synthetase (AdoMetS), an enzyme involved in the formation of $S$-adenosylmethionine which is the major methyl group donor in cells. Myrcene synthase (spot 35), a chloroplast precursor, sucrose synthase (spot 16), ATP synthase submit (spot 14), delta-selinene synthase (spot 34) and elongation factor 2 (spot 19), an important protein involved in protein synthesis, were also identified.

As an autotrophic dinoflagellate, A. catenella uses light and carbon dioxide to synthesize high energy molecules and various organic compounds through photosynthesis. Four ribulose-1,5-bisphosphate carboxylase/oxygenases (spots $1-4)$, the enzyme that catalyzes the first major step of carbon fixation, and 6-phosphogluconate dehydrogenase (spot 22) (6PGD), the enzyme that catalyzes the decarboxylating reduction of 6-phosphogluconate to ribulose 5-phosphate in the presence of NADP, were identified. Moreover, two light utilization and protection proteins, cryptochrome 2 (spots 26 and 27) and ferrochelatase (spots 28 and 29), that were highly expressed in the exponential and stationary growth phases of the A. catenella cells, were detected.

tRNA- and DNA-related proteins made up another important component of the differentially expressed proteins. Three tRNA enzymes, seryl-tRNA synthetase (spot 15), glycyl-tRNA synthetase, beta chain (spot 38) and tRNAdelta (2)-isopentenyl pyrophosphate transferase (spot 31) were identified by the database search. One DNA repair helicase Rad3-related protein (spot 33) that was annotated as being involved in maintaining DNA stability was also identified.

Heat shock proteins (Hsps) are among the most commonly found stress-related proteins in various organisms. Several Hsps from A. catenella including Hsp70 (spot 30), Hsp83 (spot 25) and Hsp90 (spots 32, 37) were identified in this study, indicating that the Hsps play important roles in the adaptation of A. catenella to environmental stress. In eukaryotic organisms, cell division is regulated by cyclins and CDKs. Two differentially expressed proteins that were annotated as being involved in the cell division of A. catenella, the filamentation induced by cAMP protein (Fic, spot 21 ) and cell division protein (spot 24), were also identified in this study.

In addition, LuxR family transcriptional regulator (NysRI, spot 36), tetratricopeptid TPR_2 repeat protein (spot 39) and several hypothetical or uncharacterized proteins (spots 17, 18, 20 and 23) were also identified among the A. catenella proteins and their expressions varied with the growth phases and/or conditions. 


\section{Discussion}

\subsection{Differential protein expression patterns in $A$. catenella during different growth phases}

In natural seawaters, HAB outbreaks can be divided into four distinct phases: initiation, development, blooming and dissipation. However, the mechanism of HAB generation is poorly understood and HABs occur unexpectedly. In eukaryotic cells, cell growth is coupled to the cell cycle which is regulated by both cyclins and CDKs, and their interactions drive the cell through the different stages of the cell cycle and subsequently regulate cell growth. Recently, CDKs have been found in species that cause HABs. Leveson et al. [10] identified a proliferating cell nuclear antigen (PCNA)-like protein in Gymnodinium catenatum and Amphidinium carterae. This protein was most highly expressed during the $\mathrm{S}$ phase of the cell cycle and thus may play important roles in regulating the replication of DNA during cell division. Barbier et al. [11] reported a cyclin B-like protein in Karenia brevis, which regulates the transition from the $\mathrm{G} 2$ to $\mathrm{M}$ phase. In another dinoflagellate species, Gambierdiscus toxicus, CDK2 was found to be expressed throughout the whole cell cycle, but it was active only at the later dark phase [9]. A few other CDKs have also been detected in eukaryotic cells that cause HABs $[12,19]$. These results indicate that, by modulating the cell cycle, cyclins and CDKs may play important roles in regulating cell growth and HABs. Recently, Chan et al. [13] investigated differential protein expression in Prorocentrum triestinum at different cell cycle stages and growth phases using a proteomic approach and found that some phasespecific proteins varied with the cell cycle and growth phase. A group of preblooming proteins (PBs), PB1, PB2 and PB3, were prominently expressed in the vegetative stages, and a group of blooming proteins (BP), BP1 and BP2, were highly expressed and greatly enhanced only in the blooming stages; however, all these phase-specific proteins decreased markedly in the dissipation phase. BP1 was up-regulated during mitosis and down-regulated after cell division, and although the general expression patterns were quite consistent during $24 \mathrm{~h}$. Based on the results of their study, Chan et al. [13] postulated that the phase-specific PBs and BPs might have functional roles in modulating cell growth and cell proliferation; however, these roles are yet to be characterized.

In the present study, the differential protein expressions of $A$. catenella under different growth phases were investigated and several groups of proteins were found to vary significantly with the growth phases. Among the differentially expressed proteins, nine isoforms of AdoMetS that were highly expressed in all growth phases were identified; the only exception to this was in the dissipation phase where they were barely visible. In archaea, bacteria, and eukaryotes, AdoMetS catalyzes the formation of $S$-adenosylmethionine (SAM) from methionine and ATP, and thereby plays a central role as the methyl donor for various proteins, nucleic acids and polysaccharides, as well as for many of the metabolites that are associated with the primary and secondary metabolism of cells [28,29]. Tabor et al. [30] found that AdoMetS was involved in the biosynthesis of the polyamines that are required for cellular proliferation and which may play a role in the rapid growth of bloom-forming dinoflagellates [31]. Recently, Ho et al. [32] reported that in the dinoflagellate Crypthecodinium cohnii, the expression of both the transcript and the protein of AdoMetS peaked at the G1 phase during the cell cycle; they also observed that the expression of the AdoMetS protein was high on day 1 of the fast growing log phase. Ho et al. [32] suggested that AdoMet-mediated DNA methylation may play a role in the regulation of cell proliferation in $C$. cohnii. In the present study, the high expression of AdoMetS in A. catenella at the initial, exponential and stationary phases suggested that increased biosynthetic activity occurred during these phases, consistent with the earlier characterizations of these phases, and indicated that AdoMetS might play an important role in regulating the cell proliferation and growth of A. catenella. Thus, variations in AdoMetS expression may reflect the biosynthetic activity of cells and potentially could be used as an indicator of cell activity.

$\mathrm{RuBisCO}$ has been found in most autotrophic organisms from prokaryotes (photosynthetic and chemoautotrophic bacteria, cyanobacteria and archaea) to eukaryotes (various algae and higher plants). RuBisCO is a bifunctional enzyme that catalyzes both the initial carboxylation reaction in the photosynthetic carbon reduction cycle and the initial oxygenation reaction in the photorespiratory carbon oxidation cycle. Dinoflagellates have been shown to express form II RuBisCO, a form of the enzyme that was previously thought to be exclusively expressed in anaerobic organisms where it is encoded by nuclear genes [33,34]. It has been reported that $\mathrm{RuBisCO}$ protein levels in the dinoflagellate species Gonyaulax were constant over time and did not vary with the carbon fixation circadian rhythm [35]. In the present study, RuBisCO (spots 2 to 5) was found to be highly expressed and, except in the dissipation phase, no differences in expression were detected in any of the other growth phases. In the dissipation phase, the RuBisCO spots were barely visible, reflecting the lack of photosynthesis activity $\left(\mathrm{CO}_{2}\right.$ fixation) in this phase.

In this study, no known cyclins or CKDs were detected in any of the growth phases in A. catenella; however, two proteins, Fic and a cell division protein, with differential expression patterns and annotated as being involved in regulating cell division, were found. Fic was highly expressed in the initial phase, while the cell division protein was expressed in all growth phases except for the dissipation phase, indicating that their roles in regulating cell proliferation and growth may be different. Fic is a regulation factor in the cell division of some bacteria where it is involved in the synthesis of p-aminobenzoate or folate. It has been suggested that 
the Fic protein and cAMP are involved in the regulation of cell division via folate metabolism in Escherichia coli, and that cell division might be controlled by the coordination of cAMP, and the Fic and Fts proteins [36]. In bacteria, the cell division protein appeared to be involved in the initiation of cell division [37] where it assembled into a cytokinetic ring on the inner surface of the cytoplasmic membrane where division occurs. The high expression of the cell division protein throughout the whole growth phase of $A$. catenella in this study, suggested that this protein may be important in regulating cell division.

Group 3 proteins that varied with the growth phases were most highly expressed in the exponential and/or stationary phases; these proteins included cryptochrome, ferrochelatase, heat shock proteins, and DNA/tRNA related proteins. Cryptochromes are a class of blue light photoreceptors in plants and animals where they play important roles in regulating germination, elongation, photoperiodism, and other responses in higher plants [38] and are involved in the circadian rhythms of plants and animals [39]. Ferrochelatase catalyzes the terminal step in the biosynthesis of heme by converting protoporphyrin IX to the heme that is required in chloroplasts mainly for the cofactors of PSII and the cyt b6/f complex [40]. Heme is also a cofactor in some component of the mitochondrial electron transport chain and in various nonchloroplast hemoproteins (for example, the catalases and peroxidases). In the green algae Chlamydomonas reinhardtii, the level of ferrochelatase in the cells is synchronized to the light/dark cycle and shows no significant variation with the phase of the cycle [41]. In A. catenella, the highest cryptochrome and ferrochelatase expressions were detected in the exponential phase, indicating that the highly light-regulated physiological activities (photosynthesis, signal transduction and biosynthesis) occurred in the exponential growth phase of the cells.

Hsps are commonly used as biomarkers for cellular stress in various organisms [42]. Here, several Hsps, Hsp 70, Hsp 83 and Hsp 90, were found to be highly expressed in the exponential phase, suggesting that the cells may experience elevated levels of cellular stress under bloom conditions. Previous studies have demonstrated that the activity of antioxidant enzymes of Peridinum gatunense was enhanced by increased oxidative stress as the density of bloom cell increased $[43,44]$. Furthermore, several proteins involved in tRNA biosynthesis and DNA repair were most highly expressed in the exponential phase of A. catenella growth, confirming that high DNA and RNA transcriptional activity occurs in the phase of exponential growth. All these proteins potentially could be used as biomarkers to indicate the exponential growth phase of A. catenella.

\subsection{Differential protein expression patterns of $A$. catenella under environmental stresses}

In coastal waters, dinoflagellate cells encounter different environmental stresses, such as nutrient limitations, suboptimal temperatures and light conditions. However, few studies have investigated the stress response in dinoflagellates, and the cellular mechanisms by which dinoflagellates adapt to environmental stresses are still poorly understood. Miller-Morey and Van Dolah [18] investigated the physiological responses of $K$. brevis to various environmental stresses and identified a number of stress proteins and antioxidant enzymes in this organism. They found that Hsp 60, Fe superoxide dismutase (Fe SOD) and Mn SOD were induced when $K$. brevis was exposed to elevated temperatures, hydrogen peroxide, or lead, while the mitochondrial small Hsps (mitosHsps) responded only to heat and the chloroplastic small Hsps (chlsHsp) responded only to hydrogen peroxide-induced stress. They suggested that the mitosHsps and chlsHsps may be suitable candidate biomarkers of physiological stress in K. brevis. Chan et al. [13] compared the protein expression profiles of $P$. triestinum under various stress conditions and found that the 2-DE protein profiles were marginally different under different stress condition; however, significant changes in the protein profiles were observed when compared with the protein profiles in the blooming culture under the same stress conditions. In the study of Chan et al., Group 1 proteins showed a dramatic increase in relative abundance while Group 2 proteins declined in abundance and were barely detectable under stress conditions. Moreover, the PB1, PB2 and PB3 proteins were expressed in high abundance and remained high under stress conditions. The expression of BP1 was low, and BP2 was only observed in nitrogen-limited $P$. triestinum.

In the present study, the protein profiles of A. catenella under nitrate- and phosphate-starved, light and temperature stress conditions were investigated. Compared with the 2-DE protein profiles of the exponential culture, the majority of proteins, especially the proteins from groups 1 and 2, in A. catenella grown under nitrate- and phosphate-starved conditions, significantly declined or were barely detectable. The expressions of proteins from Group 3 were not affected by phosphate-starvation while the proteins were not visible in the 2-DE gels of the nitrogen-starved cells. After the addition of nitrate or phosphate, the majority of proteins showed a dramatic increase in relative abundance; however, nitrate addition did not enhance the expression of proteins from groups 1 and 2 . These results indicated that the proteins from groups 1 and 2 were regulated by both nitrate and phosphate, while proteins from Group 3 were modulated more by nitrate than by phosphate. Moreover, the cellular response to nutrient addition was fast and, after the addition of phosphate, the phosphate-starved culture possessed a higher potential for growth than the nitrate-starved cells after the addition of nitrate. This finding differs from a previous study in $P$. triestinum that demonstrated that nitrogen-limited cultures possessed a higher potential for growth [13]. The difference in the results may be caused by dinoflagellate species, A. catenella may contain more phosphate 
in its intracellular pools than P. triestinum.

Light and temperature are two important factors that regulate the cell growth of dinoflagellates in the ocean. Suboptimal light and temperature will affect cell growth and proliferation. A few studies have shown that dinoflagellate cells can survive in extreme light and temperature conditions; however, the biochemical mechanism behind this ability is poorly understood. Many studies have demonstrated that stress proteins and antioxidant enzymes are the first cellular stress response to environmental stresses in various organisms $[45,46]$. In the present study, the proteins from Group 3, cryptochrome, ferrochelatase, Hsp 70, Hsp 83 and Hsp 90, and several other proteins involved in tRNA biosynthesis and DNA repair, were overexpressed in continuously illuminated cells compared to the exponential cells; while they were expressed at low levels or were barely visible in other growth conditions. Previous studies have shown that, in plants, cryptochromes and ferrochelatase protect cells from high light intensity and are regulated by light, at least at the mRNA level $[47,48]$. In C. reinhardtii, the ferrochelatase content is higher in cells grown in continuous light than those grown in the dark [41], consistent with our results. Chaperone Hsps have been found in dinoflagellates and have been shown to be upregulated in proportion to the severity of the stress encountered $[18,49]$. Thus, the overexpression of the Group 3 proteins in this study suggested that these proteins are potential 'biomarkers' that could be used to indicate the physiological response of cells to light stress. There was no significant difference between the 2-DE protein profiles of A. catenella grown under low temperatures for short times and the 2-DE protein profiles of $A$. catenella at the reference exponential phase; however, the proteins from groups 1 and 2 and the majority of Group 3 proteins were poorly expressed or were not visible when grown at low temperature for 10 days, indicating that, over time, these proteins were sensitive to temperature. Some of the Group 3 proteins, the cryptochromes, ferrochelatase and Hsp 83 and Hsp 90, were unaffected by temperature and maintained relatively high expressions, indicating that these proteins may play important roles in maintaining some basic physiological activities that are essential to cell survival at low temperature.

\section{Conclusions}

This study demonstrated that proteomic analysis is a powerful tool for physiological studies of dinoflagellates. The analysis presented here provides a first insight into the phase-specific and stress proteins in A. catenella. Some of the proteins from A. catenella that are specifically related to the different growth phases and to environmental stress (nutrient, light and temperature) were identified. A majority of the growth phase-specific proteins, such as AdoMetS, RuBisCO and Hsps, were associated with macromolecular biosynthesis, photosynthesis, stress response and cell cycle regulation, in agreement with the expected roles of these proteins in cell physiology. In continuous illumination condition, proteins related to light utilization and protection, such as cryptochromes, ferrochelatase and Hsps were overexpressed; these proteins were not observed or were expressed at low levels in the other conditions that were studied. The results suggest that the proteins identified in the present study play important roles in regulating cell growth and proliferation as well as in protecting cells from environmental stresses, and it is proposed that these proteins are potential biomarkers of the different growth phases and physiological stresses in these cells.

We thank Dr. Hai-Feng Gu from the Third Institute of Oceanography of SOA, China for providing the A. catenella DHO1 samples. We acknowledge the Genome Research Center, The University of Hong Kong, China for technical assistance on MALDI TOF-TOF MS analysis and data searching. This work was partially supported by the National Key Basic Research Program of China (2010CB428703), the National Natural Science Foundation of China (40876059 and 40776068), the Excellent Group and the Program for New Century Excellent Talents in Xiamen University, to D-Z Wang.

1 Anderson D M, Garrison D J. Ecology and oceanography of harmful algal blooms. Limn. Oceanogr, 1997, 42: 1009-1305

2 Cembella A D. Ecophysiology and metabolism of paralytic shellfish toxins in marine microalgae. In: Anderson D M, Cembella A D, Hallegraeff G M, eds. Physiological Ecology of Harmful Blooms. Berlin Heidelberg: Springer-Verlag, 1998. 381-403

3 Hallegraeff G M. Harmful algal blooms: A global overview. In: Hallegraeff G M, Anderson D M, Cembella A D, eds. Manual on Harmful Marine Microalgae. Paris: Imprimerie Landais, 2005. 25-49

4 Anderson D M, Cembella A D, Hallegraeff G M. Physiological Ecology of Harmful Blooms. Berlin Heidelberg: Springer-Verlag, 1998. 662

5 Rizzo P J. The enigma of the dinoflagellate chromosome. J Protozool, 1991, 38: 246-252

6 Hackett J D, Anderson D M, Erdner D L, et al. Dinoflagellates: A remarkable evolutionary experiment. Amer J Bot, 2004, 91: 1523-1534

7 Wong J T Y, Kwok A C. Proliferation of dinoflagellates: Blooming or bleaching. BioEssays, 2005, 27: 730-740

8 Nurse P. Ordering S phase and M phase in the cell cycle. Cell, 1994, 79: 547-555

9 Van Dolah F M, Leighfield T A, Sandel D H, et al. Cell division in the dinoflagellate Gambierdiscus toxicus is phased to the diurnal cycle and accompanied by activition of the cell cycle regulatory protein, CDC2 kinase. J Phycol, 1995, 31: 395-406

10 Leveson A, Wong J T Y. PCNA-like proteins in dinoflagellates. J Phycol, 1999, 35: 798-805

11 Barbier M, Leighfield T A, Van Dolah F M. Cell cycle regulators in the Florida red tide dinoflagellate, Gymnodinium breve. J Phycol, 2000, 36: 4-12

12 Lam C M C, New D, Wong J T Y. cAMP in the cell cycle of the dinoflagellate Crypthecodinium cohnii (Dinophyta). J Phycol, 2001, 37: 79-85

13 Chan L L, Hodgkiss I J, Wan J M F, et al. Proteomic study of a model causative agent of harmful algal blooms, Prorocentrum triestinum II: The use of differentially expressed protein profiles under different growth phases and growth conditions for bloom prediction. Proteomics, 2004, 4: 3214-3226

14 Schofield O, Grzysmki J, Moline M, et al. Impact of temperature acclimation on photosynthesis on the toxic red tide dinoflagellate Alex- 
andrium fundyense (Ca28). J Plankton Res, 1998, 20: 1241-1258

15 Parkhill J P, Cembella A D. Effects of salinity, light and inorganic nitrogen on growth and toxigenicity of the marine dinoflagellate $\mathrm{Al}$ exandrium tamarense from northeastern Canada. J Plankton Res, 1999, 21: 939-955

16 Sullivan J M, Swift E, Donaghay P L, et al. Small-scale turbulence affects the division rate and morphology of two red-tide dinoflagellates. Harmful Algae, 2003, 2: 183-199

17 Etheridge S M, Roesler C S. Effects of temperature, irradiance, and salinity on photosynthesis, growth rates, total toxicity, and toxin composition for Alexandrium fundyense isolates from the Gulf of Maine and Bay of Fundy. Deep Sea Res Part II: Topical Studies in Oceanography, 2005, 52: 2491-2500

18 Miller-Morey J S, Van Dolaha F M. Differential responses of stress proteins, antioxidant enzymes, and photosynthetic efficiency to physiological stresses in the Florida red tide dinoflagellate, Karenia brevis. Comp Biochem Physiol C, 2004, 138: 493-505

19 Chan L L, Lo S C L, Hodgkiss I J. Proteomic study of a model causative agent of harmful red tide, Prorocentrum triestrinum, I: Optimization of sample preparation methodologies for analyzing with two dimensional electrophoresis. Proteomics, 2002, 2: 1169-1186

20 Akimoto $\mathrm{H}, \mathrm{Wu} \mathrm{C}$, Kinumi T, et al. Biological rhythmicity in expressed proteins of the marine dinoflagellate Lingulodinium polyedrum demonstrated by chronological proteomics. Biochem Biophys Res Commun, 2004, 315: 306-312

21 Chan L L, Hodgekiss I J, Lu S H, et al. Use of 2-DE proteome reference maps of dinoflagellates for species recognition of causative agents of harmful algal blooms. Proteomics, 2004, 4: 180-192

22 Wang D Z, Li C, Dong H P, et al. Homology-driven proteomics of dinoflagellates with unsequenced genome by MALDI-TOF/TOF and automated de novo sequencing. Evidence-Based Complementary and Alternative Medicine, 2011, doi: 10.1155/2011/ 471020.

23 Wang D Z, Dong H P, Li C, et al. Identification and characterization of cell wall proteins of a toxic dinoflagellate Alexandrium catenella using 2-D DIGE and MALDI TOF-TOF mass spectrometry. Evidence-Based Complementary and Alternative Medicine, 2011, doi: 10.1155/2011/984080

24 Zhou M J, Yu R C. Mechanisms and Imp acts of harmful algal blooms and the countermeasures. Chin J Nat, 2007, 29: 72-77

25 Zhou M J, Zhu M Y. Progress of the project "Ecology and Oceanography of Harmful Algal Blooms in China". Adv Earth Sci, 2006, 21 : 673-679

26 Keller M D, Selvin R C, Claus W, et al. Media for the culture of oceanic ultraphytoplankton. J Phycol, 1987, 23: 633-638

27 Wang D Z, Lin L, Chan L L, et al. Comparative studies of four protein preparation methods for proteomic study of the dinoflagellate Alexandrium sp. using two-dimensional electrophoresis. Harm Algae, 2009,8: 685-691

28 Catoni G L. S-Adenosylmethionine: A new intermediate formed enzymatically from L-methionine and adenosinetriphosphate. J Biol Chem, 1953, 204: 403-416

29 Chiang P K, Gordon R K, Tal J, et al. S-adenosylmethionine and methylation. FASEB J, 1996, 10: 471-480

30 Tabor H, Rosenthal S M, Tabor C W. The biosynthesis of spermidine and spermine from putrescine and methionine. J Biol Chem, 1958, 233: 907-914
31 Chan K L, New D, Ghandhi S, et al. Transcript levels of the eukaryotic translation initiation factor 5A gene peakat early G (1) phase of the cell cycle in the dinoflagellate Crypthecodinium cohnii. Appl Environ Microbiol, 2002, 68: 2278-2284

32 Ho P, Kong K F, Chan Y H, et al. An unusual S-adenosylmethionine synthetase gene from dinoflagellate is methylated. BMC Mol Biol, 2007, 8: 87-102

33 Morse D, Salois P, Markovic P, et al. A nuclear-encoded form II RuBisCO in dinoflagellates. Science, 1995, 268: 1622-1624

34 Rowan R, Whitney S M, Fowler A, et al. RuBisCO in marine symbiotic dinoflagellates: Form II enzymes in eukaryotic oxygenic phototrophs encoded by a nuclear multigene family. Plant Cell, 1996, 8: 539-553

35 Nassoury N, Fritz L, Morse D. Circadian changes in ribulose-1,5-bisphosphate carboxylase/oxygenase distribution inside individual chloroplasts can account for the rhythm in dinoflagellate carbon fixation. Plant Cell, 2001, 13: 923-934

36 Komano T, Utsumi R, Kawamukai M. Functional analysis of the fic gene involved in regulation of cell division. Res Microbiol, 1991, 142: 269-277

37 Lutkenhaus J. FtsZ ring in bacterial cytokinesis. Mol Microbiol, 1993 9: 403-409

38 Lin C T. Plant blue-light receptors. Trends Plant Sci, 2000, 5: 337342

39 Cashmore A R, Jarillo J A, Wu Y J, et al. Cryptochromes: Blue light receptors for plants and animals. Science, 1999, 284: 760

40 Dailey H A, Dailey T A, Wu C K, et al. Ferrochelatase at the millennium: Structures, mechanisms and [2Fe-2S] clusters. Cell Mol Life Sci, 2000, 57: 1909-1926

41 Van Lis R, Atteia A, Nogaj L A, et al. Subcellular localization and light-regulated expression of protoporphyrinogen IX oxidase and ferrochelatase in Chlamydomonas reinhardtii. Plant Physiol, 2005, 1104: $105-118$

42 Feder M E, Hofmann G E. Heat-shock proteins, molecular chaperones, and the stress response: Evolutionary and ecological physiology. Annu Rev Physiol, 1999, 61: 243-282

43 Butow B, Wynne D, Tel-Or E. Seasonal and environmental influences on antioxidative protection in Peridinium gatunense in Lake Kinneret. J Appl Phycol,1996, 8: 403-407

44 Vardi A, Berman-Frank I, Rozenberg T, et al. Programmed cell death of the dinoflagellate Peridinium gatunense is mediated by $\mathrm{CO}_{2}$ limitation and oxidative stress. Curr Biol, 1999, 9: 1061-1064

45 Fridovich I. Superoxide anion radical $\mathrm{O}_{2}$, superoxide dismutases, and related matters. J Biol Chem, 1997, 272: 18515-18517

46 Bierkens J G E A. Applications and pitfalls of stress-proteins in biomonitoring. Toxicology, 2000, 153: 61-72

47 Chow K S, Singh D P, Walker A R, et al. Two different genes encode ferrochelatase in Arabidopsis: Mapping, expression and subcellular targeting of the precursor proteins. Plant J, 1998, 15: 531-541

48 Kleine T, Kindgren P, Benedict C, et al. Genome-wide gene expression analysis reveals a critical role for CRYPTOCHROME1 in the response of Arabidopsis to high irradiance, Plant Physiol, 2007, 144: 1391-1406

49 Okamoto O K, Hastings J W. Novel dinoflagellate clock-related genes identified through microarray analysis. J Phycol, 2003, 39: $519-526$

Open Access This article is distributed under the terms of the Creative Commons Attribution License which permits any use, distribution, and reproduction in any medium, provided the original author(s) and source are credited. 